\title{
Analysis of Non-Government Organizations Position in Filling Pre-Trial for the Purpose of Determining the Suspect
}

\author{
Peter Jeremiah Setiawan $^{1}$, Lolita Fitriyana ${ }^{2}$, Puri Indah Sukma Negara ${ }^{3}$, Novia \\ Choirunnisa $^{4}$ \\ ${ }^{1}$ Faculty of Law, Universitas Surabaya, Indonesia \\ ${ }^{2,3,4}$ Faculty of Law, Universitas Airlangga, Indonesia \\ Peterjsetiawan@staff.ubaya.ac.id,lolitafitriyana31@gmail.com,puriindah1408@gmail.com, \\ novia.choirunnisa@gmail.com
}

\begin{abstract}
After Decision of the Constitutional Court Number 98 / PUU-X / 2012, NGO include third parties with an interest in submitting pretrial proceedings by terminating investigations or terminating proceedings, but related to Post- Decision of Constitutional Court Number 21 / PUU-XII / 2014, it can be seen that there is an extension of pre-trial proceedings, one of which is the suspect's determination. It actually raises concerns about pre-trial object posed by NGO, whether or not it requires the determination of a suspect, it given that it is not written if it looks at grammatically. Based on background above, this research analyzes about first, can non-governmental organizations submit pre-trial applications for the purpose of determining a suspect? Secondly, what is the concern of juries' respect to the position of Non-Governmental Organization that submitted a pre-trial application for the purpose of determining the suspect? This research is a normative legal research with an approach to laws, a philosophical approach and a case approach. Based on this research, it has been identified that First, NGO should first submit pre-trial applications for the purpose of assessing a suspect. Whereas, since Article 77(a), which is incidentally the subject-matter of pre-trial proceedings for $N G O$, has been extended, it should be interpreted that NGO also send pre-trial applications for the purpose of determining the suspect. Secondly, in some justices' reflections based on Constitutional Court's Decision Number: 98 / PUU-X / 2012 on May 21, 2013 jo. The justice considered, in Constitutional Court Decision Number 21/PUU-XII/2014, that the complainant as an $N G O$ has a legal role in bringing a preliminary ruling against the object of suspect's determination.
\end{abstract}

Keywords

non-government organizations, pre-trial; determining of suspect

\section{Introduction}

In provision considering Law No.8 of 1981 concerning Law of Criminal procedure which incidentally constitutes the key points of thinking that are the context and justification for the establishment of a statutory regulation (S., 2007), it is mentioned that:

The Republic of Indonesia is a constitutional state based on Pancasila and the Constitution of 1945, which upholds human rights and guarantees equal status in law and government for all citizens and is obliged, without exception, to uphold the law and government (thickening of the author);... 
It can be seen from these provisions that one of the foundations for the birth of Law $8 / 1981$ is the guarantee of human rights, and it is one of the features of the rule of law (Sayuti, 2011). In addition, the spirit of protecting human rights in Law 8/1981 is also compatible with the opinion of Said Abdullah, which states (Abdullah, 2010):

At the end of 1981, the implementation of our National Criminal Procedure Code was a great relief and offered fresh hope for realization of the New Order's objectives in the field of legal justice. In addition, in its justification, as well as in the final opinion of the factions in the DPR, this Criminal Procedure Code (hereinafter referred to as KUHAP) emphasizes the importance of the KUHAP regulating the protection to human dignity

The regulation of the pretrial application mechanism is one of the concrete aspects of protection of human rights in Law 8/1981 (Sitorus, 2015). This is in line with opinion of I Gede Yuliartha, who stated that it relates to pre-trial objectives, whereas (Yuliartha, 2009): "In the pre-trial process, the objectives to be established and protected, are the upholding of the law and the upholding of the law 'The pre-trial opinion related to the concretization of the existence of protection of human rights in Law 8/1981 is, in fact, reasonable, in recognition of the way that pre-trial was established to conduct a horizontal monitoring of the acts of coercion performed on the suspect during the investigation or prosecution. -It is true that the conduct does not contradict the laws and regulations (Azis, 2014).

It is regulated, on the interpretation of Article 77 of Law 8/1981, that pre-trial objects are:

a. Whether or not this is legal to arrest, arrest, suspend investigation or punish;

b. Compensation and or rehabilitation for a criminal at level of investigation or prosecution whose criminal case is terminated.

The existence of pre-trial object was eventually increased by Decision No 21/PUUXII/2014 of Constitutional Court, which mentioned that (Setiawan et al., 2020): "Article 77(a) is contrary to international Law of 1945 and does not have binding legal force as long as it is not interpreted, including determination of suspects, searches and confiscations." With this expansion, it can be seen that in pretrial Indonesia there are 3 (three) new objects created. There are 9 (nine) pretrial objects in Indonesia, are:

1. Whether or not the arrest is legal,

2. Whether or not the detention is constitutional

3. Constitutional or termination of investigation

4. Whether or not the termination of a prosecution is legal

5. If a suspect's determination is legal or not

6. If the application is or is not valid

7. Whether or not the confiscation is lawful

8. Compensation for a person whose criminal case at the level of investigation or prosecution is terminated

9. Rehabilitation at the level of investigation or prosecution for a criminal whose criminal case is terminated 


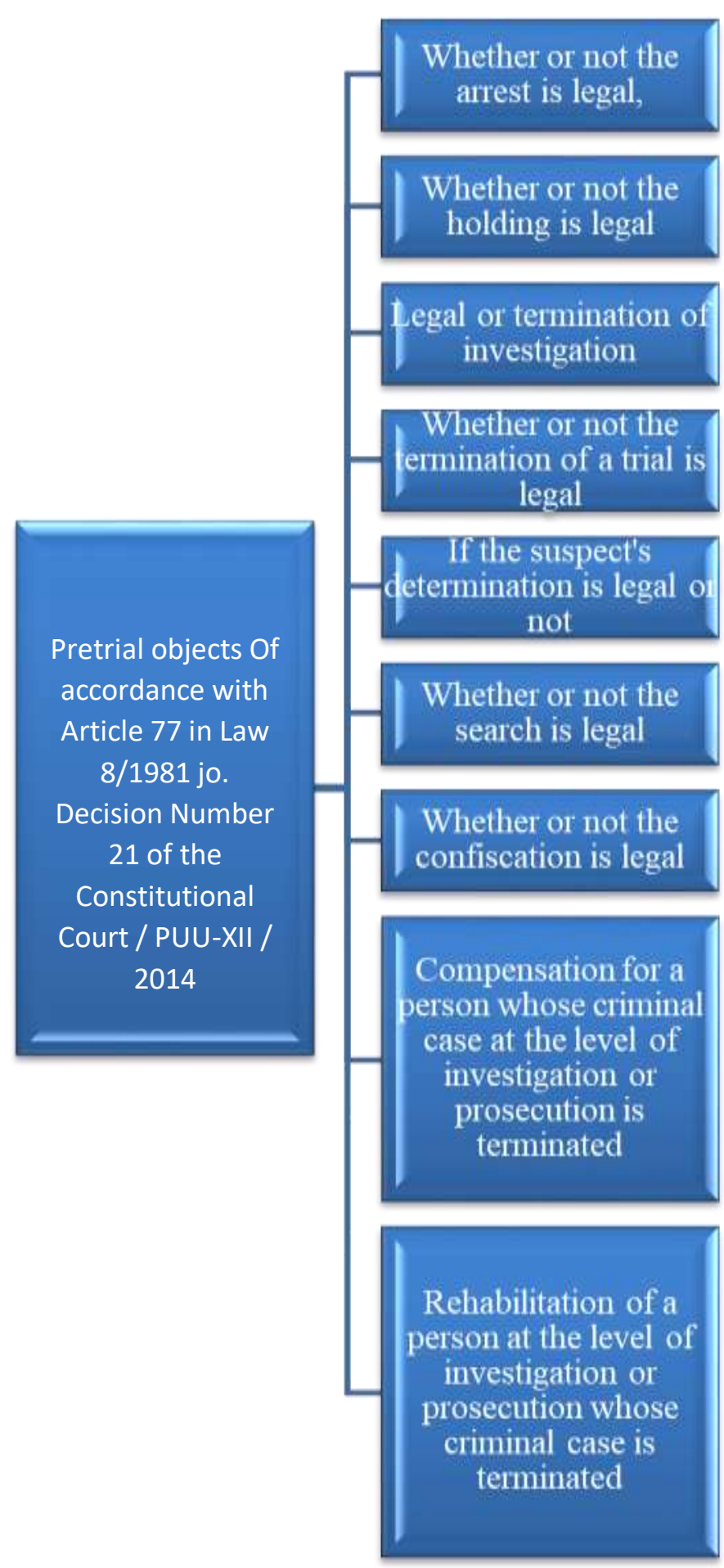

Figure 1. The pre-trial Object

Source: Management Results by Author

In meanwhile, the submission of a pre-trial application regarding legality of an action before pre-trial by law enforcement officials cannot, of necessity, be filed carelessly. There under context of filing pre-trial, there's many conditions. One of these is related to human entities that are entitled to file a pre-trial application or are usually referred to as legal entities. That legal standing is concept used to determine whether the applicant is sufficiently concerned and legally protected, so the applicant is authorized to file a pre-trial action (Ramdan, 2014) 
In terms of legal standing in filing of a pretrial, it is actually regulated by Act 8/1981. The parties have even been established by Law 8/1981, and what pre-trial conditions may be provided, such that the subjects in pre-trial between one party and another are not automatically the same. In addition, as regards parties and their reasons for filing a pre-trial as provided for in Law 8/1981, (Yuristia, 2016)

1. Suspect, Legal Advisor or Family Counsel.

Article 79 of the Code of Criminal Procedure provides that victims, their families and their lawyers have the right to apply to the Chairman of District Court a review of the lawfulness of an arrest or detention. What can be submitted to pre-trial is, according to this article, just a matter of arrest and detention, although other actions, such as searches and confiscation, have still not been recorded directly.

2. Third Party Public Prosecutor or Concerned.

One of the powers of pre-trial, as explained previously, is to review whether or not the termination of the investigation or prosecution by law enforcement officers, particularly investigators and public prosecutors, is legal. If the investigator ceases investigation in a criminal case without a reason justified by law, then public prosecutor and the relevant parties are required to report to pre-trial conference.

3. The suspect, his heir, and the lawyer

In accordance with the provisions of Article 95(2) of the Code of Criminal Procedure: 'Claims for damages for arrest or incarceration by suspect or his heirs and other actions without justification or due to errors relating to person or law referred to in paragraph (1) in respect of which the case is not brought before District Court shall be determined at pre-trial hearing on the basis that person or law referred to in paragraph (1) is wrong.

4. Suspects or parties concerned seek compensation.

Mentioned in Article 81 of Code of Criminal Procedure, which is to say, demands for compensation and/or rehabilitation as a result of illegal arrest or detention or as a result of legal termination of an investigation or prosecution submitted to Leader of District Court by defendant or third party concerned, specifying the reasons for the investigation or prosecution.

On the background of these provisions, it can be seen that a concerned third party is one of parties which has legal standing in request of a pre-trial relating to review of whether or not the termination of investigation or prosecution is legal. Initially, this caused confusion about who third parties concerned were. A non-governmental organization (NGO) is one of the third parties discussing whether or not it is part of an interested third party.

After the Constitutional Court Decision Number 98 / PUU-X / 2012, the controversy over the position of NGO as an interested third party then ended. In Decision No 98 / PUU-X / 2012 of a Constitutional Court, it is mentioned that: 'The term 'interested third party' is contrary to the Constitution of 1945 and has no binding legal force unless it has been interpreted. "Including victim witnesses or reporters, non-governmental organizations or community organizations" Indeed, the existence of Decision No 98/PUU-X/2012 of Constitutional Court has confirmed that NGO are an interested third party so that they can submit a pre-trial related to the investigation of whether or not the termination of investigation or prosecution is legal or not (Kafara, 2020)

In addition, Decision Number 98/PUU-X/2012 of Constitutional Court bring an end to the controversy over the position of non-governmental organizations as third parties with an interest in applying pre-trials by terminating investigations or terminating prosecutions, but after Decision Number 21/PUU-XII/2014 of Constitutional Court, It can 
be seen that there is an expansion of pretrial objects, one of which is the suspect's determination. This actually expresses concern about pre-trial object presented by NGO, whether or not it concerns the determination of a suspect, given that it is not written if you look at it grammatically.

In form of polemic relating to NGO can apply pre-trial applications for the purpose of determining a suspect can be seen in Decision Number 11/Pid.Pra/2018/PN Smg. and Decision Number 153/Pid.Prap/2018/PN.Jkt.Sel. In 2 (two) decision, it can be seen that there is a polemic regarding the legal standing of NGO in submitting pretrial applications related to the determination of the suspect. In Decision Number 11/Pid.Pra/2018/PN Smg justice decided, that NGO has legal standing, because of the extension of legal standing based on the Constitutional Court Decision Number 98/PUU-X/2012. Then, in Decision Number 153/Pid.Prap/2018/PN.Jkt.Sel, the justice governed that NGO did not have legal standing. There 2 (two) decisions that seem to be paradoxical, it shows that related to pretrial requests by NGO for the purpose of determining suspect, in fact, there is still the potential for multiple interpretations. Based on it, the problem formulations in this research are:

1. Can non-government organizations submit pre-trial applications for the purpose object of determining a suspect?

2. What is the concern of juries' respect to the position of the Non-Governmental Organization that submitted a pre-trial application for the purpose of determining the suspect?

\section{Research Methods}

This research is a study of the law. Legal research is a method for the determination of legal laws, legal concepts and legal doctrines to solve the legal issues at hand (Marzuki, 2017). The aim of this legal research is to identify legal laws, legal principles and legal doctrines to deal with legal issues related to the role of non-governmental organizations in application of pre-trial applications for purpose of determining the suspect.

A type of normative legal research is being used in the type of research. The research carried out to gather and analyze secondary data is normative legal research (Marzuki, 2017)Usually, only secondary data sources are used in normative legal research, like books, diaries, laws and regulations, court judgments, legal theories and the opinions of leading legal scholars.

The legislation approach, conceptual approach, and case approach are the approaches used in this legal research. The regulatory method is carried out by reviewing all laws and other regulations that are in question relating to legal issues, so that the ratio legist is found, ontological basis and philosophical basis of regulations (Agustine, 2018). The statutory regulations analyzed in this legal research are laws and regulations relating to the role of NGO in submitting pre-trial applications in order to determine the suspect. Conceptual approach is an approach that moves from views and doctrines that develop in science of law to analyze existence of legal problems (Barus, 2017). The legal concepts used in this legal research are legal concepts to address legal questions related to position of non-governmental organizations in submitting pre-trial applications for the purpose of determining the suspect. Case approach is an approach that uses judges' decisions as a source of legal material. These ddecisions are judges' decisions that have permanent legal force. The matter discussed in the court decision which has legal force is in the ratio decidendi, are the legal reasons used by the judge in determining the decision (judgment) (Budiyanto, C., Prananto, Tan, F, 2019). The judges' decisions being analyzed in this research are those related to the position of in providing pre-trial applications for purpose of determining the suspect. 


\section{Results and Discussion}

\subsection{NGO as Pretrial Petitioners to Determine the Alleged Criminal}

Legal rules, particularly legal emptiness (leemten in het recht), conflicts between laws (legal antinomies), and undefined laws (vague recht) or undefined laws, are often conditions in the identification of legal rules.(Taqiuddin, 2017). An explanation of these 3 (three) concerns is provided follows. (Abbas, 2017):

1. Legal vacuum is a condition in which something is not regulated by a national principle;

2. A court case is a situation in which a regulation has been established but is contrary or not in accordance with other regulations;

3. Legal obscurity is a situation in which the regulation already exists but has no clear meaning or more than one meaning is established by the norm that renders the norm blurry or uncertain.;

It can be said that there is legal ambiguity in the context of legal issues relating to position of NGO in submitting pre-trial applications with a purpose to determining the suspect. This is because there are already regulations regarding pre-trial requests by NGO in the status a quo, but it is not clear whether or not the authority of NGO is the determination of suspects who are actually an extension of the specific topic of pre-trial requests.

In addition, these are established scientifically that the research of legal science does not allow legal obscurity $(\mathrm{R}, 2020)$. This is closely related to the legal certainty principle embraced in Indonesia on basis of Article 28D (1) UUD NRI 1945, in addition, with regard to pre-trial for NGO which incidentally play a big part in the implementation of legal protection for the society. M. Yahya state that, NGO or social organizations ought to have been given space as parties to propose pre-trials, and as an organization that intends to oversee law enforcement, if the aim of pre-trial is to correct or control out is termination errors or arbitrariness, then there is appropriate justification to argue that it is reasonable to consider the desire to involve the wider community represented by NGO or social organizations in the pre-trial filing process. (Harahap, 2002). On basis of the importance of NGO in pre-trial filing, regulations that regulate pre-trial objects for NGO must be established in the future legal development.. This is done so that pre-trial measures for NGO would have a clear position in Indonesia's law and regulation.

In addition, the urgency of setting up NGO in pre-trial filing for the purpose of determining the suspect can be seen in the Constitutional Court Decision Number 98/PUUX/2012 and Constitutional Court Decision Number 21/PUU-XII/2014.

\section{a. Constitutional Court Decision Number 98/PUU-X/2012}

In judges's consideration [3.14] Constitutional Court Number 98/PUU-X/2012, mentioned that:

Contravening the interpretation of the phrase "interested third parties"' of Article 80 UU 8/1981, A judgement has been issued by Court in case Number 76/PUU-X/2012 on January 8, 2013, which in consideration, as follows:

- Paragraph [3.15] state that, “...Whereas the Code of Criminal Procedure does not provide a clear interpretation of who, according to the Court, can be classified as an interested third party, what is meant by an interested third party is not only a witness who is a victim of a crime or a reporter, but it must also be interpreted broadly. Thus, the interpretation of third parties in $a$ quo article is not only limited to victim witnesses or reporters, but must also cover the wider community, which in this case can be represented by associations of people with interests and the same 
objective is to struggle for public interests, such as non-governmental organizations or other community organizations, because the Criminal Procedure Code is essentially a legal instrument for the application of criminal law. Criminal law is a law for both the defense of public interests."; (author's thickening)

- Paragraph [3.16] state that, “...in regulation of law enforcement, community development, whether individual citizens or associations of people who have the same interests and objectives to fight for the public interest (public interest advocacy), is needed. In some of judgments, the Court, as guardian of Constitution, has defined the legal position in application of a request for judicial review, which is not confined to individual Indonesian citizens but also organizations of individuals who share similar values and objectives (public interest advocacy) to fight for the public interest, including various organizations and non-governmental organizations (NGO) or NGO concerned with public interest regulations..."; (author's thickening)

\section{b. Constitutional Court Decision Number 21/PUU-XII/2014}

In judges's consideration [3.16] Constitutional Court Decision Number 21/PUUXII/2014 letter $\mathrm{k}$, mentioned that:

...Since the determination of a suspect is part of an investigation procedure that constitutes a violation of international law, the determination of a suspect by the investigator should be an object that can be obtained by pre-trial organizational legal efforts for protection. It is solely to protect an individual from inappropriate actions by an investigator which are likely to occur when someone is deemed a suspect, as there is a flaw in the process, so there is no other institution that can examine and decide it other than pre-trial. Defending the interests of a suspect does not, however, It mean that the suspect is innocent and does not leave the allegation of a criminal act, so that further investigations can be carried out in accordance with the relevant and ideal legal principles. The inclusion of legality of a suspect's identification as an object of pre-trial order means that the consideration of a person in criminal trials takes into account the suspect as a human being who, before the law, has equal equality, dignity and position. (author's thickening).

If it constructs a synthesis from legal considerations of Constitutional Court Decision Number 98/PUU-X/2012 and Constitutional Court Decision Number 21/PUU-XII/2014, It can be seen that NGO that are generally seen as representations advocating for the public interest find it logical if they are concerned in determining the suspect, because the suspect's determination can conflict with the public interest.

According to Philippe Nonet and Philip Selznick, legal development related to pretrial petitions for NGO for the purpose of determining the suspect is actually a form of good legal development is sensitive legal development. According to Philippe Nonet and Philip Selznick, responsive legal development, is (Selznick, 2018):

"Legal products with responsive features indicate that the production process is participatory, which indicates that it absorbs social groups and individuals' participation in society, absorb desires related to social changes, and bsorbing the aspirations of people on a large scale in order to crystallize the different competing wills of society. The space of government to produce interpretation $n$ (interpretation) are too determined by own vision and political power is also confined by responsive legal products. However, a legal product that expresses a 
sense of justice and follows social expectations. Meanwhile, the opposite happens in a law product with a conservative character, (author's thickening)."

It can be stated that the arrangement of pre-trial petitions with the aim of determining suspects by NGO is a concretization of responsive legal development in the context of community development, which clearly remembers human rights as very important and sees NGO as representatives of the community.

In addition, the legal development solution, in form of regulations responsible for the regulation of pre-trial applications for the purpose of determining suspects by NGO is a futuristic solution or ius constituendum. However, this solution still does not address legal issues concerning to the a quo status relating to legal obscurity with regard to the role of NGO in submitting pre-trial applications for the purpose of determining the suspect. Quod non, There is a legal formation relating to the regulation of pre-trial applications for the purpose of determining the suspect by NGO, but this does not solve a quo status legal problems, even though there is a potential for pre-trial filing for the purpose of determining the suspect by NGO. Do not let it be too late for the community to obtain justice, which should be the community's right, on the condition that the rule of law has not been established. It would contradict the conventional legal adage is justitiae non est neganda, non differenda (Justice is not to be denied or delayed.) (Wicaksono, 2020).

The method of legal interpretation must be used in order to respond to legal problems related to the vagueness of legal norms. Legal interpretation in context of undefined legal standards is the activity of knowing and understanding something (Zamroni, 2020). There are two basic differences in legal interpretation method are interpretation and construction (Mawar, 2016). If regulations exist, the method of legal interpretation is enforced, but it is not obvious that they can be extended to specific events, whereas legal construction is carried out in the event that regulations do not exist.. (Sutiyoso, 2006). In casu a quo, o regard to the position of non-governmental organizations in the presentation of pre-trial applications for the purpose of determining the suspect which, incidentally, represents a legal obscurity, it is more appropriate to determine the legal interpretation in the form of a legal interpretation.

A systematic interpretation is the legal interpretation which can be used to answer NGO position in submitting pre-trial applications for the purpose of determining the suspect. Extensive interpretation is a method of interpretation by grammatical interpretation, allows an interpretation beyond the ordinary limit (Muwahid, 2017). To clarify a statutory provision beyond the limits of grammatical interpretation, comprehensive interpretation is used to explain (Sutiyoso, 2006). In casu a quo, in Article 77 letter a UU 8/1981, regulated that: "In accordance with the provisions established in this legislation, district courts are authorized to examine and decide in regard to: a. Whether it is legal or not to arrest, charge, end the investigation or court;" In Article 80 UU 8/1981 jo. Constitutional Court Decision Number 98/PUU-X/2012, it is stipulated that the investigator or public prosecutor or an interested third party through submit a request to examine whether or not the termination of the investigation or prosecution is legal if one of the third parties concerned is an NGO. Article 77 letter is expanded based on Constitutional Court Decision Number 21/PUU-XII/2014 Whether arrest, detention, termination of investigation or prosecution, suspect recognition, search, and confiscation were legal or not. It can also be interpreted that Article 77(a), which is incidentally the topic of pre-trial proceedings for NGO, is generalized, it must be interpreted that NGO can also submit pre-trial applications for the purpose of determining a suspect. 


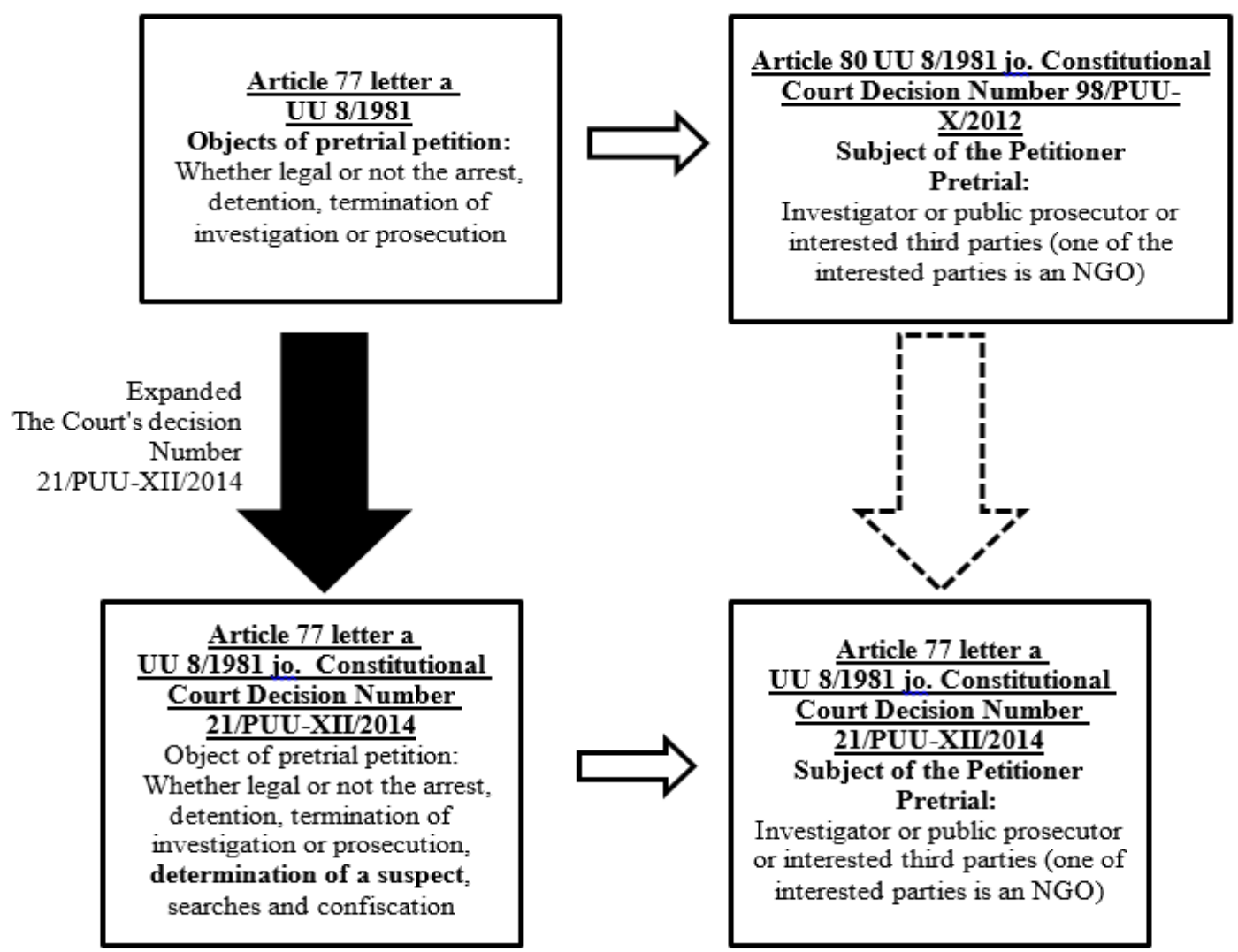

Figure 2. Extensive Interpretation Position of NGO in Filing Pretrial Applications for the Purpose of Determining the Suspect

Source: Author Management Results

On the basis of this comprehensive interpretation, it is hoped that the judge considering an incidental pre-trial application for the purpose of determining the suspect by NGO would state that the NGO has legal standing.

\subsection{Considerations of Judges Concerning the Position of Non-Governmental Organizations Filing Pretrial Applications for the Determination of a Suspect}

In this article, there 2 (two) decisions have been analyzed, is Decision Number 11/Pid.Pra/2018/PN Smg. and Decision Number 153/Pid.Prap/2018/PN.Jkt.Sel. Two considerations have choosen by reasons:

1. 2 (Two) decisions are decisions concerning pre-trial petitions submitted by nongovernmental organizations for the purpose of determining a suspect.

2. 2 (Two) decision is a decision adopted in the context of the decision of the Constitutional Court Number. 98/PUU-X/2012 and Constitutional Court Decision Number 21/PUU-XII/2014

3. 2 (Two) Decisions Have Permanent Legal Impact (inkracht van gewijsde);

4. An overview of 2 (two) decisions is given below.

\section{a. Decision Number 11/Pid.Pra/2018/PN Smg}

This decision stems from the presence of the 'PEJUANG ANTI-KRIMINALISASI' Group of Non-Governmental Organizations, which has submitted a pre-trial application for the determination of a suspect against Arif Wijaya, S.T. Together with Albert Riyadi Suwono, S.H., M.Kn. (Citizens 'Share). The determination of the suspect stems from 
existence of Police Report Number: LP/B/2/I/2017/Jateng/Reskrimsus on January 3, 2017 and then there's an Order Number of Investigation: SP.Sidik/21/I/ 2017/Reskimsus on January 10, 2017 and the determination of respective suspect is created, an. Arif Wijaya, S.T. on August 8, 2017 and an. Albert Riyadi Suwono, S.H., M.Kn. on September 25, 2017 on suspicion of falsification and/or laundering money of letters (Pasal 263 KUHP and/or Article 3 Jo. Article 5 UU No. 8 of 2010). As for the object of a criminal act in the report is " ASSET REPORT BOOK Number: DPS.006/ LHP.GEAR/2016 on February 1, 2016 issued by KJPP "GUNTUR, EKI, ANDRI \& PARTNERS" Denpasar Branch." Regarding the Determination of the suspect with object, it has actually been reported to Surabaya Polrestasbes, debfab Police Report Number: LP/457/B/XII/2016/JATIM/POLRESTABES SURABAYA / SEK SKM on December 28, 2016, and there is an Investigation Order Number: SP.Sidik/457/XII/2016/Reskrim on December 28, 2016, but the development in the title of a case on May 30, 2017, Investigator from Sukomanunggal Polrestabes Surabaya Police decided to issue an SP3 / Letter of Termination of Investigation Number : SPPP/02/VI/2017/Reskrim on June 8, 2017.

The existence of this double investigation led to NGO "PEJUANG ANTIKRIMINALISASI ", which in fact operates in field of community activists who oversees performance and government policies in the territory of Republic of Indonesia in order to protect the abuse / abuse from submitting a pretrial with the aim of double investigations like what happened to the suspect ARIF WIJAYA, ST. and ALBERT RIYADI SUWONO, SH., M.Kn. (Part of Society), In order to avoid a poor precedent for the broader community to support legal education / learning in the center of society today, it does not happen to other communities. The legal basis used by NGO PEJUANG ANTI-KRIMINALISASI ' argues that, on the basis of Constitutional Court Decision Number 98/PUU-X/2012.

The Respondent then submitted the exception to a persona standi in judicio (not an individual who has rights and interests), where the Respondent argued that the Constitutional Court Decision Number 98/PUU-X/2012 Decision of the Constitutional Court of Republic of Indonesia Number: 98/PUU-X/2012 on May 21, 2013 it applies to non-governmental organizations concerned with the prevention of corruption, while NGO PEJUANG ANTI-KRIMINALISASI'. The respondent also submitted an exception obscuur libel on the ground that the subject-matter of a quo pretrial petition did not follow the rules set down in the provisions of Articles 77 to 83 of Code of Criminal Procedure and the Decisions of the Constitutional Court.

In legal considerations, related to exception of persona standi in judicio, the justice in Decision Number 11/Pid.Pra/2018/PN.Smg In essence, it states, that the reason for the Respondent's exception is that the pretrial petition is flawed formally, due to disqualification in person, the Petitioner is not a persona standi in judicio (not a person who has rights and interests), on the basis as described in points a through e, according to the judge, it is not correct, because in Decision of the Constitutional Court in Republic of Indonesia Number: 98/PUU-X/2012 on May 21, 2013 It is true that those who make requests for judicial review are NGOs that only have concerns about the prevention of corruption, but what is being tested is formal law regarding Criminal Procedure Law, not material law regarding Corruption Crime, therefore based on the Constitutional Court decision Number : 98/PUU-X/2012 on May 21, 2013 The Petitioner as a non-governmental organization is the party entitled to submit a pretrial application, so that the justice in his decision rejects the Respondent's exception related to the exception persona standi in judicio.

Furthermore, in legal considerations regarding the exception of obscuur libel, the justice was of opinion that the petition from NGO regarding the determination of the 
suspect was not obscure. Judge in Decision Number 11/Pid.Pra/2018/PN.Smg mentioned that: "The Determination of a Suspect is an object of the pretrial as the Constitutional Court Decision Number 21/PUU-XII/2014." Based on these considerations, if interpreted a contra rio, it can be interpreted that $a$ quo pretrial petition is in accordance with rules stipulated in the provisions of articles 77 to article 83 in Criminal Procedure Code and Constitutional Court Decisions Number 21/PUU-XII/2014.

Based on these considerations, it can be seen that the justice in Decision Number 11/Pid.Pra/2018/PN.Smg Interpreting that NGO can file a pretrial with the object of determining the suspect.

\section{b. Decision Number 153/Pid.Prap/2018/PN.Jkt.Sel}

This decision originated from the existence of a "TIM PEMBELA KEADILAN" which submitted a pretrial application against Denny Indrayana for alleged corruption in the implementation / implementation of Payment Gateway at the Ministry of Law and Human Rights. RI T.A 2014 based on Police Report No..: LP/226/II/2015/Bareskrim, on February 24, 2015. The Petitioner argued that based on information there was an SP3 against Denny Indrayana. In petition, the petitioner requested that the criminal case on behalf of the suspect Denny Indrayana be submitted to the Court immediately. The legal basis for legal standing proposed by the petitioner was the Constitutional Court Decision based on the Constitutional Court Decision Number 98/PUU-X/2012.

The Respondent then submitted an exception related to legal standing. The Respondent argued that based on the Constitutional Court Decision Number 98/PUUX/2012 on March 21, 2013 It was emphasized that Non-Governmental Organizations (NGO) or Mass Organizations (Ormas) were indeed given the right to sue as an interested third party, but in NGO decision it was an association that had the same interests and goals in order to fight for the public interest (public interests advocacy) which incidentally must meet the requirements, among others: has a legal entity, in its Articles of Association it is emphasized that the organization's interests are established and the organization has carried out real activities in the eradication of the crime.

In legal consideration, related to this legal standing exception, the justice stated:

Considering, whereas concerning interested third parties who may propose

Pre-Trial as dictum Decision of the Constitutional Court No. 76/PUU-X/2012 on January 2, 2013, jo Constitutional Court Decision Number 98 / PUU-X / 2012 on May 21, 2013 namely in the form of associations of people who have the same interests and goals to fight for the public interest (public interests advocacy): is non-governmental organizations or social organizations "; from evidence P.1 to P.27 The court has not obtained evidence that can prove that the Petitioners are non-governmental organizations or social organizations "; in Articles of Association of their Organization and their activities have the same interests, interests and goals to fight for the public interest ( public interests advocacy) even though the Petitioners gave the name of their group / Joined the TIM PEMBELA KEADILAN (author's thickening).

From the legal considerations, the justice in his decision then granted the defendant's exception, so that the pretrial petition was not accepted.

In Decision 11/Pid.Pra/2018/PN Smg. In Decision Number 153/Pid.Prap/2018/PN.Jkt.Sel, If analyzed, both decisions acknowledge pretrial requests by NGOs with object of determining a suspect. Indeed, on the Decision 153/Pid.Prap/2018/PN.Jkt.Sel rejects the existence of an NGO request from the TIM PEMBELA KEADILAN, but it needs to be noted that the rejection is not depend of TIM 
PEMBELA KEADILAN is an NGO, but it is unable to present evidence which prove that the Petitioners are NGO with interests, interests and goals, the same to fight to the public interest (public interests advocacy). On this basis, it can be interpreted contra rio, that if the TIM PEMBELA KEADILAN presents evidence which can prove that the Petitioners are NGO with the same interests, interests and goals to fight for public interests (public interests advocacy), the pretrial petition can be granted.

\section{Conclusion}

NGO can submit pretrial applications with the object of determining a suspect. This is based on extensive interpretations. Whereas, since Article 77 letter a which incidentally is the object of pretrial for NGO has been expanded, it should be interpreted that NGO can also submit pretrial applications with the object of determining a suspect. On the basis of this extensive interpretation, it is hoped that the justice who incidentally will be confronted with a pre-trial application with the object of determining the suspect by NGO states that NGO has legal standing.

In Decision Number 11/Pid.Pra/2018/PN.Smg, based on the decision of Constitutional Court Number: 98/PUU-X/2012 tanggal 21 Mei 2013 jo. Constitutional Court Decision Number 21/PUU-XII/2014,the justice considered that the Petitioner as an NGO has legal standing in submitting a pretrial against the object of determining the suspect. On Decision Number 153/Pid.Prap/2018/PN.Jkt.Sel, The justice decided the exception regarding the legal standing of the Respondent, because according to the judge, the Petitioners were unable to present evidence could prove that the Petitioners were NGO with the same interests, interests and goals to fight for public interests (public interests advocacy). On this basis, it can be interpreted contra rio, that if the JUSTICE DEFENSE TEAM presents evidence which can prove, the Petitioners are NGO with the same interests, interests and goals to fight for public interests (public interests advocacy) the pretrial petition can be granted

\section{References}

Abbas, A. R. I. (2017). Tinjauan Yuridis Kewajiban Penggunaan Bahasa Indonesia Bagi Tenaga Kerja Asing Di Indonesia. Novum: Jurnal Hukum, 4(1), 4.

Abdullah, S. (2010). Segi-Segi Pokok HAM Dalam Kuhap. Jurnal Lex Specialis, Edisi Khusus, 2.

Agustine, O. V. (2018). Jurisprudence Enforceability on Judicial Review Authority in the Constitutional Court Decision. Jurnal Konstitusi, 15(3), 643.

Azis, A. S. dan A. (2014). Hukum Acara Pidana. Kencana Prenada Media Group.

Barus, Z. (2017). Analisis Filosofis Tentang Peta Konseptual Penelitian Hukum Normatif Dan Penelitian Hukum Sosiologis. Dinamika Hukum, 13(2), 313.

Budiyanto, C., Prananto, Tan, F, T. (2019). Designing Embedded Case Study Research Approach in Educational Research. International Journal of Pedagogy and Teacher Education, 3(1), 1-18.

Harahap, M. Y. (2002). Pembahasan Permasalahan dan Penerapan KUHAP (edisi kedua). Sinar Grafika.

Kafara, S. (2020). Analisis Hukum Pelaksanaan Putusan Praperadilan terhadap Perkara Setya Novanto oleh Komisi Pemberantasan Korupsi (Nomor 97/Pid.Prap/2017/PN.Jkt-Sel tanggal 29 September 2017). Jurnal Penegakan Hukum Dan Keadilan, 1(1), 88. 
Marzuki, P. M. (2017). Penelitian Hukum : Edisi Revisi. Kencana Prenada Media Group.

Mawar, S. (2016). Metode Penemuan Hukum (Interpretasi Dan Konstruksi) Dalam Rangka Harmonisasi Hukum. Justitia, 1(1), 10.

Muwahid. (2017). Metode Penemuan Hukum (Rechtsvinding) Oleh Hakim Dalam Upaya Mewujudkan Hukum Yang Responsif. Al-Hukama, 7(1), 225-248.

R, A. S. R. S. (2020). Perundang-Undangan di Indonesia, Kajian mengenai Ilmu dan Teori Perundang-Undangan serta Pembentukannya,. Social Political Genius.

Ramdan, A. (2014). Problematika Legal Standing Putusan Mahkamah Konstitusi. Jurnal Konstitusi, 11(4), 739.

S., M. F. I. (2007). Ilmu Perundang-Undangan 1 Jenis, Fungsi, dan Materi Muatan. Kansius.

Selznick, P. N. P. (2018). Hukum Responsif. Nusa Media.

Setiawan, P., Nugraha, X., \& Enrick, M. (2020). Analisis Kedudukan Keterangan Korban Terkait Kejahatan Terhadap Harta Kekayaan Dalam Lingkungan Keluarga: Sebuah Antinomi Antara Hukum Materil Dengan Formil. Al-Daulah: Jurnal Hukum Pidana Dan Ketatanegaraan, 9(1), 99-118.

Sitorus, D. (2015). Efektivitas Pra Peradilan Dalam Rangka Perlindungan Hak Asasi Manusia Berdasarkan Undang-Undang Nomor 8 Tahun 1981 Tentang Kitab UndangUndang Hukum Acara Pidana Di Wilayah Hukum Pengadilan Negeri Bengkalis. JOM Fakultas Hukum, 2(1), 2.

Sutiyoso, B. (2006). Metode Penemuan Hukum. UII Press.

Taqiuddin, H. U. (2017). Penalaran Hukum (Legal Reasoning) Dalam Putusan Hakim. Jurnal Ilmu Sosial Dan Pendidikan, 1(2), 193.

Wicaksono, M. B. R. (2020). Assessing The Rights Of Women Victims Of Home Violence During The COVID-19 Pandemic. Lex Scientia, 4(2), 12.

Yuliartha, I. G. (2009). Lembaga Praperadilan Dalam Perspektif Kini Dan Masa Mendatang Dalam Hubungannya Dengan Hak Asasi Manusia. Law Reform, 5(1), 7.

Yuristia, R. (2016). Pengaruh Putusan Mahkamah Konstitusi Nomor 21/PUU-XII/2014 Terhadap Pengajuan Praperadilan Mengenai Penetapan Status Ongky Syahrul Ramadhona Sebagai Tersangka. Jurnal Verstek, 4(3), 182.

Zamroni. (2020). Penafsiran Hakim dalam Sengketa Kontrak : Kajian Teori dan Praktik Peradilan. Scopindo Media Pustaka. 